Ambiente \& Água - An Interdisciplinary Journal of Applied Science
ISSN 1980-993X - doi:10.4136/1980-993X
www.ambi-agua.net
E-mail: ambi.agua@gmail.com

\title{
Simultaneous removal of nitrogen and organic carbon from swine wastewater using the pre-denitrification/nitrification process
}

\author{
ARTICLES doi:10.4136/ambi-agua.2241
}

Received: 12 Feb. 2018; Accepted: 29 Jan. 2019

\author{
Marcelo Bortoli $^{*}$; ; Airton Kunz ${ }^{2,3}$; Marina Celant De Prá4 ${ }^{(D)}$; \\ Marcio Luis Busi Da Silva ${ }^{2}$; Ana Cé5 ${ }^{5}$; Hugo Moreira Soares 6 \\ ${ }^{1}$ Universidade Tecnológica Federal do Paraná (UTFPR), Francisco Beltrão, PR, Brasil \\ Programa de Pós-graduação em Engenharia Ambiental (PPGEA). \\ Departamento Acadêmico de Engenharia Ambiental (DAEAM). E-mail: marcelobortoli@utfpr.edu.br \\ ${ }^{2}$ Embrapa Suínos e Aves, Concórdia, SC, Brasil \\ E-mail: airton.kunz@embrapa.br, marcio.busi@embrapa.br \\ ${ }^{3}$ Universidade Estadual do Oeste do Paraná (UNIOESTE), Cascavel, PR, Brasil \\ Programa de Pós-graduação em Engenharia Agrícola (PGEAGRI). E-mail: airton.kunz@embrapa.br \\ ${ }^{4}$ Universidade Tecnológica Federal do Paraná (UTFPR), Dois Vizinhos, PR, Brasil \\ Coordenação do Curso de Engenharia de Bioprocessos e Biotecnologia. E-mail: marinapra@utfpr.edu.br \\ ${ }^{5}$ Universidade Tecnológica Federal do Paraná (UTFPR), Francisco Beltrão, PR, Brasil \\ Programa de Pós-graduação em Engenharia Ambiental (PPGEA). E-mail: aninhace_@ hotmail.com \\ ${ }^{6}$ Universidade Federal de Santa Catarina (UFSC), Florianópolis, SC, Brasil \\ Departamento de Engenharia Química e de Alimentos. E-mail: soares@enq.ufsc.br \\ *Corresponding author
}

\begin{abstract}
Wastewater from confined animal feeding operations (CAFOs) can interfere significantly with the natural nitrogen and phosphorus balance in the environment if not treated adequately prior to disposal. In this work, a modified Lutzak-Ettinger (MLE) consisting of sequential predenitrification/ nitrification was used to determine the effects of nutrient loading rates and hydraulic retention times (HRT) on total nitrogen (TN) and organic carbon (TOC) removal from swine wastewater. MLE reactor was continuously fed swine wastewater for over 205 days using different recycle ratios (Rr) and HRT. Higher TN and TOC removal efficiencies $(90.7 \%$ and $96.1 \%$, respectively) were obtained when recycling effluent from the nitrification tank (4.5:1) combined with effluent from the final clarifier (1:1). Removal efficiencies of $96 \%$ for TOC and $90 \%$ for TN were obtained for the maximum loading rates of $0.56 \mathrm{gTN} \mathrm{L}^{-1} \mathrm{~d}^{-1}$ and $2.15 \mathrm{~g}^{\mathrm{TOC}} \mathrm{L}^{-1} \mathrm{~d}^{-1}$, respectively. TN and TOC removal rates were achieved with HRT in as little as 3.5 days. Overall, MLE was a robust bioprocess withstanding variations in wastewater physical-chemical composition and/or changes in operational conditions without significant impairment of $\mathrm{N}$ and TOC removal efficiencies.
\end{abstract}

Keywords: ammonia, high organic rate, nitrate. 


\section{Remoção simultânea de nitrogênio e carbono orgânico em efluentes da suinocultura utilizando processo pré-desnitrificação/ nitrificação}

\section{RESUMO}

Os efluentes dos sistemas de produção de animais confinados (SPACs), se não tratados adequadamente antes do descarte, podem interferir significativamente no balanço natural do nitrogênio no meio ambiente. Nesse trabalho, um sistema Lutzak-Ettinger modificado (MLE), consistindo de dois reatores sequenciais, um pré-desnitrificante (RD) e um nitrificante (RN), foi utilizado para determinar os efeitos da carga de alimentação e o tempo de retenção hidráulico (TRH), na remoção simultânea de nitrogênio total (NT) e carbono orgânico total (COT) de efluentes da suinocultura. O sistema MLE foi alimentado com efluente da suinocultura por 205 dias, usando diferentes razões de recirculação (Rr) e TRH. Foram obtidas eficiências de remoção de NT e COT $(90,7 \%$ e $96,1 \%$, respectivamente) com a recirculação do meio do RN (4.5:1) combinado com o lodo do decantador final (1:1). Essas eficiências foram obtidas com TRH de 3,5 dias e cargas de alimentação de $0,56 \mathrm{gNT} \mathrm{L}^{-1} \mathrm{~d}^{-1}$ e $2,15 \mathrm{~g} \mathrm{TOC} \mathrm{L}^{-1} \mathrm{~d}^{-1}$. Concluiu-se que o processo MLE se demonstrou robusto, resistindo a grandes variações na composição físico-química do efluente de alimentação e nas condições de operação, sem sofrer impacto importante nas eficiências de remoção de NT e COT.

Palavras-chave: alta carga orgânica, amônia, nitrato.

\section{INTRODUCTION}

Concentrated animal feeding operations (CAFOs) are increasingly being used for the enhancement of swine production. Consequently, much higher wastewater volumes are expected which, if not treated properly, could contaminate soils and water resources (Kunz et al., 2012). For instance, the presence of high organic content and nutrients (e.g., nitrogen and phosphorus) in these effluents can exacerbate biological oxygen demand (BOD) and favor eutrophication (Techio et al., 2011).

Different system configurations are considered including intermittent aeration, the use of selective membranes, sequencing batch reactors (Lee and Han, 2012), and/or the modified Ludzack-Ettinger (MLE). The MLE, also known as anoxic pre-denitrification process (Rajagopal et al., 2011; Hafez et al., 2010), was initially proposed by Ludzack and Ettinger for treatment of municipal sewage (Ludzack and Ettinger, 1962).

In the MLE, the oxidized nitrogen species $\left(\mathrm{NOx}=\mathrm{NO}_{2}{ }^{-}+\mathrm{NO}_{3}{ }^{-}\right)$are recycled into an anoxic reactor to serve as electron acceptors for heterotrophic denitrification. MLE has been used to remove TOC and nitrogen from a wide variety of effluents, including landfill leachate (Hafez et al., 2010) and wastewaters from animal farming (Castrillón et al., 2009; Vanotti et al., 2009).

In the MLE system, the NOx recycle ratio $(\mathrm{Rr})$ to the anoxic reactor can limit nitrogen removal efficiency (Tchobanoglous et al. 2014). A high $\mathrm{Rr}$ can increase the oxidation-reduction potential (ORP) in the anaerobic reactor, inhibiting denitrification. Conversely, a low $\mathrm{Rr}$ can lead to insufficient concentrations of NOx as electron acceptors, thus hindering complete denitrification. Thus, whereas the use of the MLE to remove N and TOC from swine wastewater effluents has already been demonstrated (Hafez et al., 2010; Vanotti et al., 2009), uncertainties still remain on how different Rr affects MLE system performance, especially treating CAFOs effluents.

Therefore, this study investigated the effects of different recycling ratios and nitrogen and the increase of organic loading rates (by decreasing HRT) on N and TOC removal efficiencies, using an MLE system to treat swine wastewater effluent. 


\section{MATERIALS AND METHODS}

\subsection{Experimental setup}

A schematic representation of the lab scale MLE experimental setup is shown in Figure 1. Two 5 L completely stirred bioreactors connected in series were continuously fed swine wastewater. The first bioreactor was designed to promote anaerobic denitrification. The second was aerated to stimulate nitrification. Aerobic conditions were maintained with the use of a pneumatic air pump (PowerAIR 2000) and two cylindrical air diffusers (bubble stones) placed at the bottom of the bioreactor. The nitrified mixed liquor (NML) from the nitrification bioreactor as well as the settled solid (SS) from the clarifier were both recycled into denitrification bioreactor. Peristaltic pumps (Masterflex ${ }^{\circledR}$ L/S ${ }^{\circledR}$ Standard Digital Pump) were utilized to control different $\mathrm{Rr}$ flow rates (Q) in the MLE system (Table 1).

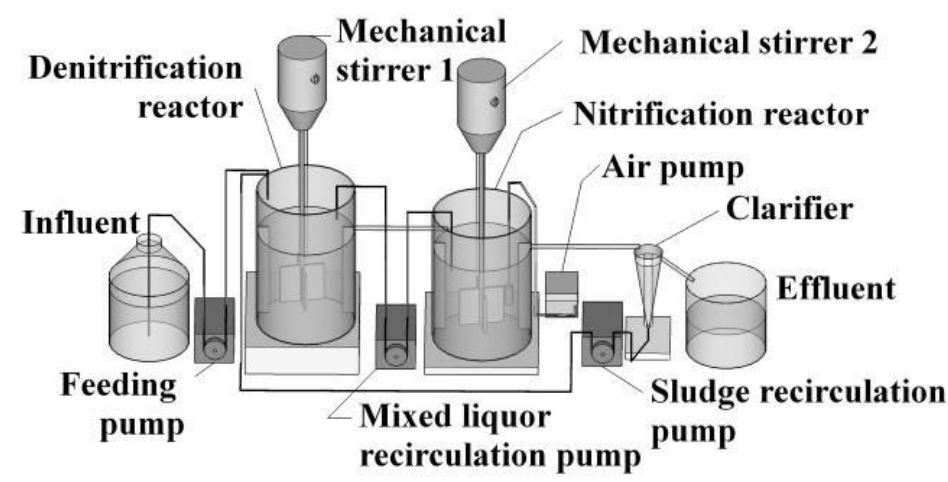

Figure 1. Schematic representation of the modified LudzakEtinger (MLE) experimental setup utilized in this work.

Table 1. MLE experimental configurations.

\begin{tabular}{lccccc}
\hline Period & $\begin{array}{c}\text { Time } \\
(\mathrm{d})\end{array}$ & $\begin{array}{c}\mathrm{Q} \text { (flow) } \\
\left(\mathrm{mL} \mathrm{min}^{-1}\right)\end{array}$ & $\mathrm{Rr}$ & $\begin{array}{c}\text { Nitrogen Loading Rate (NLR) } \\
\left(\mathrm{gN} \mathrm{L}^{-1} \mathrm{~d}^{-1}\right)\end{array}$ & $\begin{array}{c}\text { Hydraulic retention time } \\
(\mathrm{HRT})(\mathrm{d})\end{array}$ \\
\hline I & $1-126$ & 1.0 & $4-5.5-6.5$ & 0.15 & 6.9 \\
II & $127-140$ & 1.5 & 5.5 & 0.20 & 4.6 \\
III & $141-152$ & 1.8 & 5.5 & 0.24 & 3.9 \\
IV & $153-164$ & 2.0 & 5.5 & 0.30 & 3.5 \\
V & $165-185$ & 2.0 & 5.5 & 0.41 & 2.6 \\
VI & $186-196$ & 2.7 & 5.5 & 0.60 & 3.5 \\
VII & $197-205$ & 2.0 & 5.5 & 0.41 & \\
\hline
\end{tabular}

The initial HRT was calculated using Equation 1 in order to obtain the initial nitrogenloading rate (NLR) of $0.15 \mathrm{gN} \mathrm{L}^{-1} \mathrm{~d}^{-1}$ achieved by Vanotti et al. (2009) and based on the initial concentration of $\mathrm{N}-\mathrm{NH}_{3}$ from the first bath.

$$
H R T=\frac{\left[N H_{3}-N\right]}{N L R}
$$

Where:

$$
\begin{aligned}
& {\left[\mathrm{NH}_{3}-\mathrm{N}\right]=\mathrm{NH}_{3}-\mathrm{N} \text { concentratio }\left(\mathrm{g} \mathrm{L}^{-1}\right)} \\
& \mathrm{NLR}=\text { Nitrogen loading rate }\left(\mathrm{g} \mathrm{L}^{-1} \mathrm{~d}^{-1}\right)
\end{aligned}
$$

The initial calculated HRT is close to the HRTs used by other studies, mainly as a function of NLR, such as Vanotti et al. (2009) and Loughrin et al. (2009), who studied MLE systems

\section{IPABH}


for the swine wastewater treatment and used HRT between 10 and $17 \mathrm{~d}$ and 4.1 and $6 \mathrm{~d}$, respectively.

\subsection{MLE Inoculation}

Sludge from a pilot scale activated sludge bioreactor treating swine wastewater effluents at Embrapa Swine and Poultry [total suspended solids (TSS) of $7.1 \mathrm{~g} \mathrm{~L}^{-1}$ ] was used as inoculum (Viancelli et al., 2013). For the startup, the nitrification and denitrification reactors were inoculated with $0.25 \mathrm{~L}$ of inoculum and the reactor was filled with $4.75 \mathrm{~L}$ of diluted swine manure effluent (1:10 swine manure/tap water; v/v) to minimize likely inhibition by substrate restriction.

\subsection{Operational conditions}

Liquid swine wastewater effluent collected from a solid-liquid separation tank at wastewater treatment plant was utilized as feeding solution. $250 \mathrm{~L}$ of the same wastewater batch was kept under refrigeration $\left(-5^{\circ}\right)$ and utilized throughout the experimental time frame as feeding solution. Therefore, confounding effects due to variations in influent wastewater physical-chemical characteristics were avoided. The first batch $\left(\mathrm{NH}_{3}-\mathrm{N}=1.05 \mathrm{~g} \mathrm{~L}^{-1}\right)$ was used for 157 days. The second batch $\left(\mathrm{NH}_{3}-\mathrm{N}=1.36 \mathrm{~g} \mathrm{~L}^{-1}\right)$ was used from day 158 to day 205 . Different flow rates (Q), Rr, NLR, and HRT were evaluated (Table 1). It was not necessary to discard sludge from the MLE system, and consequently, the Solid Retention Time (SRT) does not need to be controlled, which reduces disposition and treatment costs.

\subsection{Analytical methods and calculation of recycle ratio and removal efficiencies}

TOC was measured in a TOC analyzer (Multi Elemental Analitic ${ }^{\circ}$ Multi C/N 2100 Analytik Jena). The $\mathrm{NH}_{3}-\mathrm{N}$ concentration was determined electrochemically by the ionselective electrode following the methodology described by APHA et al. (2012). Free ammonia (FA) and free nitrous acid (FNA) concentrations were estimated using the standard Equations proposed by Anthonisen et al. (1976).

Dissolved oxygen and $\mathrm{pH}$ were determined using an oximeter (YSI Model 55) and a $\mathrm{pH}$ meter (HANNA - HI8424), respectively. $\mathrm{NO}_{3}^{-}-\mathrm{N}$ and $\mathrm{NO}_{2}^{-}-\mathrm{N}$ were quantified by the colorimetric method using a Multi-Channel Flow Injection (FIAlab - 2500).

The recycle ratio was defined by the ratio of the recirculation flow sum (mixer liquor + sludge) by the system feed rate (Equation 2). The sludge recycle pump flow was fixed at $1 \mathrm{~mL} \mathrm{~L}^{-1}$ during the experiment.

Nitrogen removal efficiencies (NRE) were obtained after the establishment of steadyconditions in the MLE reactor according to Equation 3.

$R r=\frac{Q_{R M L}+Q_{R S}}{Q_{\text {in }}}$

Where:

$Q_{R M L}$ is nitrified mixed liquor recycle flow;

$Q_{R S}$ is clarified sludge recycle flow;

$Q_{\text {in }}$ is feeding flow.

$\operatorname{NRE}(\%)=R r \cdot(1+R r)^{-1}$ 


\section{RESULTS AND DISCUSSION}

\subsection{MLE reactors start up}

$\mathrm{NH}_{3}-\mathrm{N}$ concentrations in the batches were continuously monitored over time to account for significant losses. $\mathrm{NH}_{3}-\mathrm{N}$ concentrations in the first and second batches were $10.6 \%$ (after 165 days of storage) and $0.8 \%$ (after 40 days of storage), respectively (data not shown). The observed decrease in $\mathrm{NH}_{3}-\mathrm{N}$ influent concentrations observed in period I (Figure 2) was primarily due to dilution effects as results of the increasing recirculation ratios. Measured $\mathrm{NH}_{3}-\mathrm{N}$ concentrations at the MLE effluent were higher at the beginning of the experiments, probably due to the lack of significant nitrifying-specific biomass (Figure 2). After 32 days of continuous operation, nitrification acclimation time was reached as observed by the reduction in ammonia and the concomitant increase in effluent $\mathrm{NO}_{3}{ }^{-} \mathrm{N}$ concentrations.

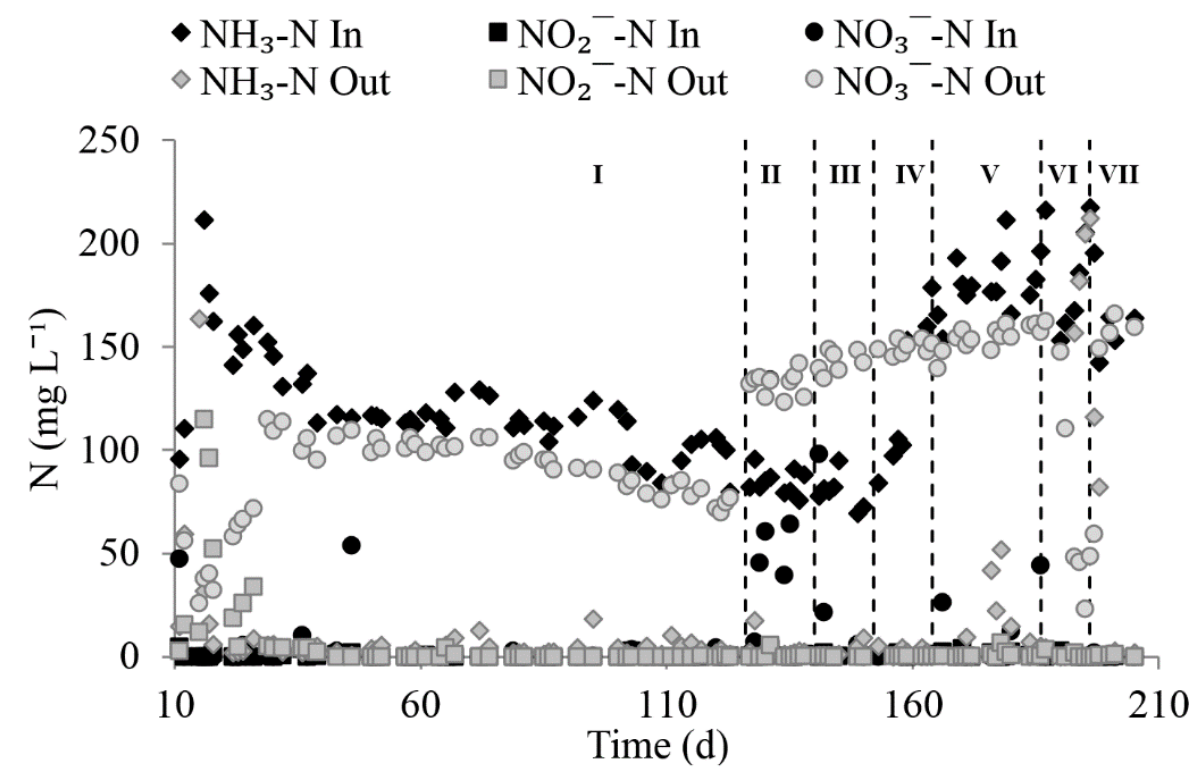

Figure 2. Nitrogen concentration profile over time in the nitrifying reactor under different reactor operational conditions (Table 1).

The average temperature $\left(23 \pm 1.6^{\circ} \mathrm{C}\right), \mathrm{pH}(7.8 \pm 0.3)$ and dissolved oxygen concentration (> $3 \mathrm{mg} \mathrm{L}^{-1}$ ) obtained during this experimental time frame were within the physiological requirements for nitrifying microorganisms (Ordaz et al., 2008). Interestingly, the observed acclimation period was much shorter than the 100 to 175 days (Jubany et al., 2008) reported for other nitrification systems treating swine wastewater. The rapid acclimation time obtained in this study was most likely due to the use of a diluted raw effluent $(1: 10 \mathrm{v} / \mathrm{v})$, which minimizes the inhibitory effects of high influent $\mathrm{NH}_{3}$ concentrations on microorganisms (De Prá et al., 2012). Therefore, the use of a diluted wastewater influent during the initial MLE start up process could minimize time required to establish steady-state conditions at field-scale operations.

To stimulate denitrification processes, the reactor was continuously fed at an influent

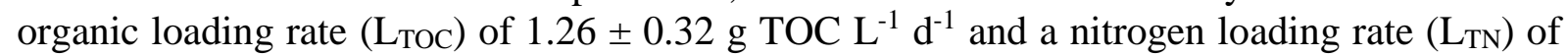
$0.15 \mathrm{~g} \mathrm{TN} \mathrm{L}^{-1} \mathrm{~d}^{-1}$. Temperature and $\mathrm{pH}$ were kept at $28 \pm 1.2^{\circ} \mathrm{C}$ and $8.4 \pm 0.2$, respectively. After 11 days of continuous operation, effluent NOx-N concentrations decreased from $52.1 \mathrm{mg} \mathrm{L}^{-1}$ to $0.21 \mathrm{mg} \mathrm{L}^{-1}$, indicating the establishment of denitrifying processes.

\subsection{MLE - Nitrification reactor performance}

After 45 days, $\mathrm{NH}_{3}-\mathrm{N}$ and TN removal efficiencies of $97.7 \%$ and $84.4 \%$, respectively, were obtained for an influent $\mathrm{L}_{\mathrm{NH}_{3}-\mathrm{N}}$ of $0.21 \pm 0.1 \mathrm{~g} \mathrm{~L}^{-1} \mathrm{~d}^{-1}$ (Period I, Figure 2). During this

\section{IPABH}


experimental time frame, dissolved oxygen (DO) $\left(3.2 \pm 0.4 \mathrm{mg} \mathrm{L}^{-1}\right)$ was unlikely limiting to nitrification because DO concentration $>2 \mathrm{mg} \mathrm{L}^{-1}$ is sufficient to maintain the growth and activity of ammonia oxidizing bacteria (AOB) and nitrite oxidizing bacteria (NOB) populations (Ordaz et al., 2008).

Changes in $\mathrm{Rr}$ from 5.5 to 6.5 decreased $\mathrm{NH}_{3}-\mathrm{N}$ removal efficiency from 96.1 to $87.5 \%$ (Figure 2). Following 86 days of experiment (Period I), however, $\mathrm{NH}_{3}$ removal efficiency reestablished from the initial 87.5 to $96.1 \%$ as result of microorganism adaptation to the newer imposed operational conditions. A further decrease in HRT (periods II, III, and IV) did not affect nitrification efficiencies, which remained within 96.4 to $98.4 \%$.

Increasing $\mathrm{NH}_{3}-\mathrm{N}$ influent loading rate by $50 \%$ (Period $\mathrm{V}$, LNH3-N of $0.39 \pm 0.1 \mathrm{~g} \mathrm{~L}^{-1} \mathrm{~d}^{-1}$ ) did not show significant changes in ammonia removal efficiencies $(93.5 \pm 4.3 \%)$, demonstrating the robustness of the MLE process to withstand variations in operational feeding rates. A decrease in HRT from $3.5 \mathrm{~d}$ to $2.7 \mathrm{~d}$ (period VI), however, led to a decrease in $\mathrm{NH}_{3}$ removal efficiency from $93.5 \pm 4.3 \%$ to $57.8 \pm 51.1 \%$. In order to re-establishment $\mathrm{NH}_{3}$ removal efficiencies, HRT was adjusted to the previous $3.5 \mathrm{~d}$.

Free ammonia (FA) concentrations in the reactor were below the inhibitory threshold reported for NOB $\left(0.1\right.$ and $\left.10.0 \mathrm{mg} \mathrm{L}^{-1}\right)$ and $\mathrm{AOB}\left(>150 \mathrm{mg} \mathrm{L}^{-1}\right)$ (Rongsayamanont et al., 2010) (Figure 3). Additionally, the absence of detectable free nitrous acid (FNA) suggested that nitrification was unlikely inhibited by the formation of FNA. Efficient $\mathrm{NH}_{3}$ oxidation ( $>99 \%$ ) was observed throughout the remaining experimental time frame (Figure 3).

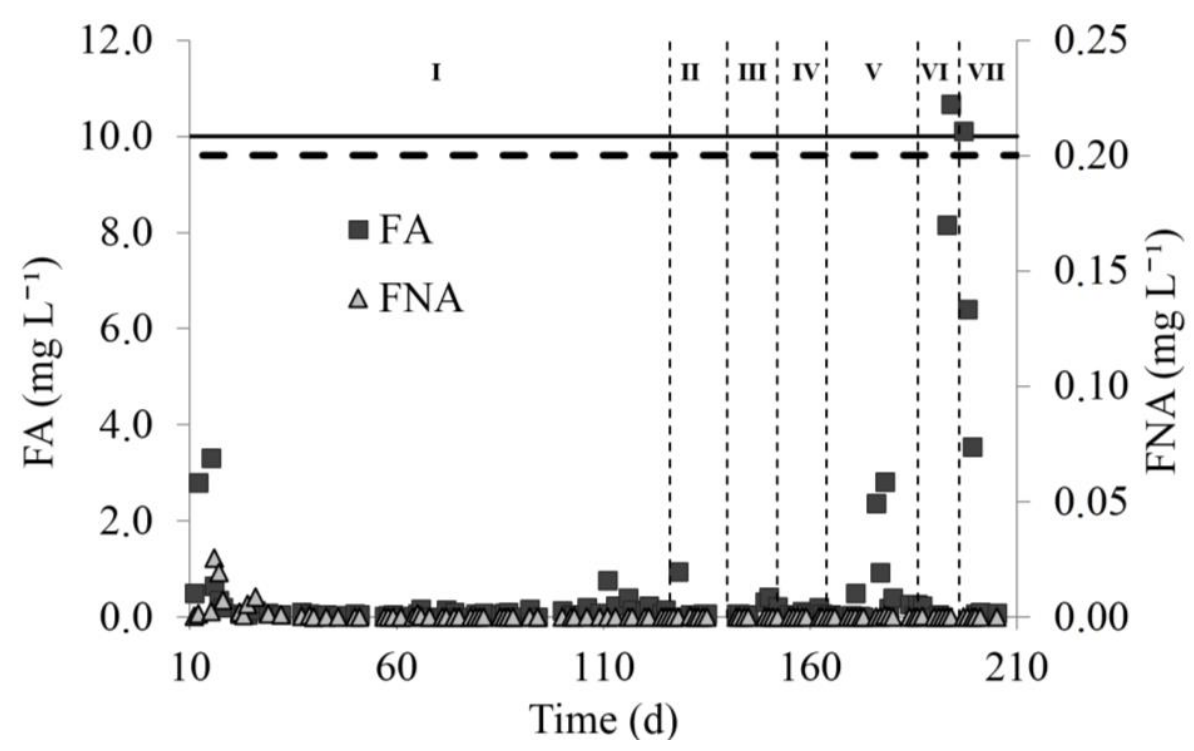

Figure 3. FA and FNA concentrations profile over time in the nitrifying reactor. Solid and dashed lines represent inhibitory thresholds for AOB and NOB, respectively (Rongsayamanont et al., 2010).

Nitrification efficiency ( $>95 \%$ ) was in agreement with previously reported data obtained for reactors treating cattle manure (Castrillón et al., 2009) or digested sow manure (Rajagopal et al., 2011). Total nitrogen removal as low as $19.1 \pm 13.2 \%$ was achieved in the nitrification reactor. This low removal value was somewhat unexpected, considering the favorable nitrification conditions in the reactor (i.e., $>2 \mathrm{mgO}_{2} \mathrm{~L}^{-1}$ and low FA concentrations). Therefore, circumstantial evidence supports the notion that other biological nitrogen removal processes were occurring concomitantly with nitrification. Whereas the investigation of such biological mechanisms was beyond the scope of this study, it is worth mentioning that biomass agglutination in MLE systems could aid the formation of anoxic micro niches, thus favoring autotrophic denitrification and/or anammox (Park et al., 2009). 


\subsection{MLE - Denitrification reactor performance}

Changes in $\mathrm{Rr}$ can play an important role in denitrification efficiency. Denitrification and TOC removal efficiencies of 88.9 and $83.5 \%$, respectively, were achieved when $\mathrm{Rr}$ was set at 4.0:1 (Period I) (Figure 4). During this experimental time frame, the reactor was fed with a $\mathrm{L}_{\mathrm{TOC}}$ of $0.41 \pm 0.1 \mathrm{~g} \mathrm{~L}^{-1} \mathrm{~d}^{-1}$ and $\mathrm{L}_{\mathrm{NOx}}$ of $0.26 \pm 0.1 \mathrm{gN} \mathrm{L}^{-1} \mathrm{~d}^{-1}$. Denitrification and TOC removal efficiencies were increased with higher influent organic and nitrogen loading rates (Figure 4). Negligible denitrification and TOC removal efficiencies were observed when raising Rr from 5.5 to $6.5: 1$. Therefore, we opted to maintain the $\mathrm{Rr}$ at 5.5:1 throughout the experiment.

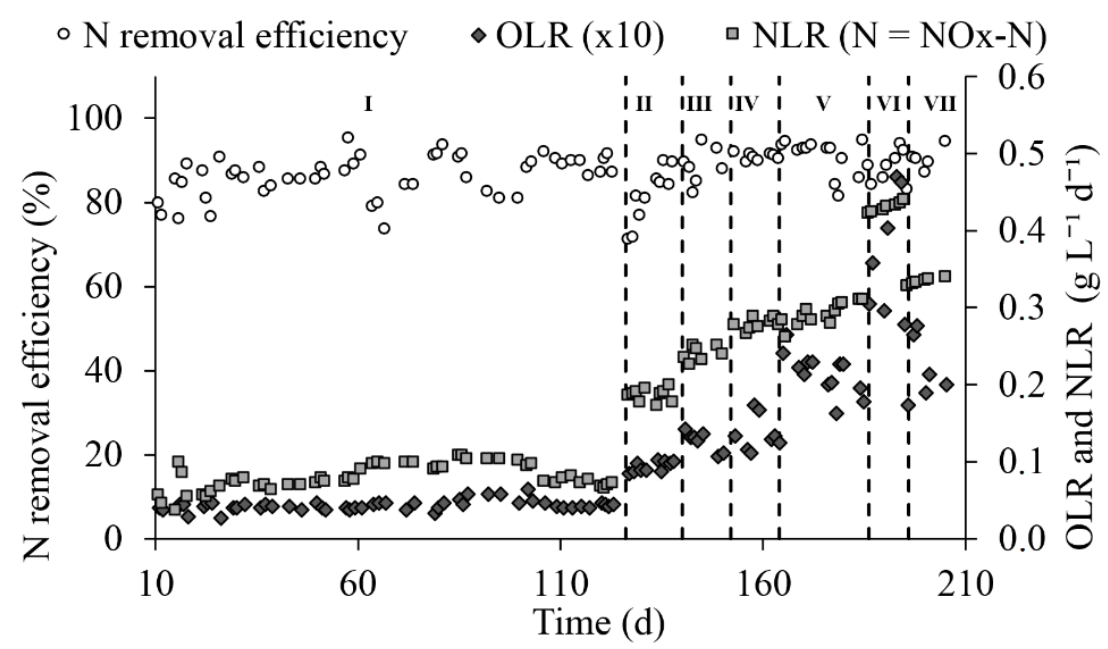

Figure 4. Correlation between Organic loading rate (OLR) and Nitrogen loading rate (NLR) on nitrogen removal efficiency by denitrification bioprocesses.

A reduction in HRT from 6.9 to 3.5 (from day 127 to 164) did not affect denitrification and TOC removal, which remained at $95.4 \%$ and $99.4 \%$, respectively. These results served to demonstrate the effectiveness of MLE to operate at relatively low HRT.

In experimental period $\mathrm{V}$, a new batch of wastewater effluent sample was used as substrate to feed the MLE system. Denitrification efficiency was kept at $99.1 \%$ with a TOC removal efficiency of $96 \%$. Interesting to note, changes in wastewater physical-chemical characteristics, such as the higher TOC, did not affect reactor efficiency. From the operational point of view, this is relevant considering the inherent variability in swine wastewater effluent composition commonly observed at field scale. After reaching steady-state conditions, the HRT was intentionally adjusted from 3.5 to $2.6 \mathrm{~d}$, resulting in an influent $\mathrm{L}_{\mathrm{TOC}}$ of $3.68 \pm 0.79 \mathrm{~g} \mathrm{~L}^{-1} \mathrm{~d}^{-1}$ and $\mathrm{L}_{\mathrm{N}-\mathrm{NOx}}$ of $0.43 \pm 0.02 \mathrm{~g} \mathrm{~L}^{-1} \mathrm{~d}^{-1}\left(0.01 \mathrm{NO}_{2}^{-} / \mathrm{NO}_{3}^{-}\right.$ratio). Even at this low HRT, the average denitrification and TOC removal efficiencies were notably high $(93.7 \%$ and $94.4 \%$, respectively).

\subsection{MLE efficiency}

Overall, the MLE system was not sensitive to major changes in nitrogen loading conditions maintaining satisfactory TOC and TN removal efficiencies of $96.1 \%$ and $90.7 \%$, respectively (for a $\mathrm{L}_{\mathrm{TOC}}$ of $2.15 \pm 0.41 \mathrm{~g} \mathrm{~L}^{-1} \mathrm{~d}^{-1}$ and $\mathrm{L}_{\mathrm{TN}}$ of $0.56 \pm 0.03 \mathrm{~g} \mathrm{~L}^{-1} \mathrm{~d}^{-1}$; Figure 5). These results were comparatively higher than the removal efficiencies reported for similar nitrificationdenitrification systems treating swine wastewater effluent. For instance, Park et al. (2009), utilizing an anoxic-aerobic-anoxic sequence reactors, obtained TN removal of $90 \%$ for a LTN of $0.18 \mathrm{~g} \mathrm{~L}^{-1} \mathrm{~d}^{-1}$. Removal efficiency below $80 \%$ was reported by Vanotti et al. (2009) for a nitrification-denitrification system using a $\mathrm{L}_{\mathrm{TN}}$ of $0.31 \mathrm{~g} \mathrm{~L}^{-1} \mathrm{~d}^{-1}$. Castrillón et al. (2009) reported $68 \%$ removal efficiency for influent $\mathrm{L}_{\mathrm{TOC}}$ of $4.5 \mathrm{gCOD} \mathrm{L}^{-1} \mathrm{~d}^{-1}$ and $\mathrm{L}_{\mathrm{TN}}$ of $0.40 \mathrm{gTN} \mathrm{L}^{-1} \mathrm{~d}^{-1}$.

\section{IPABH}

Rev. Ambient. Água vol. 14 n. 2, e2241 - Taubaté 2019 


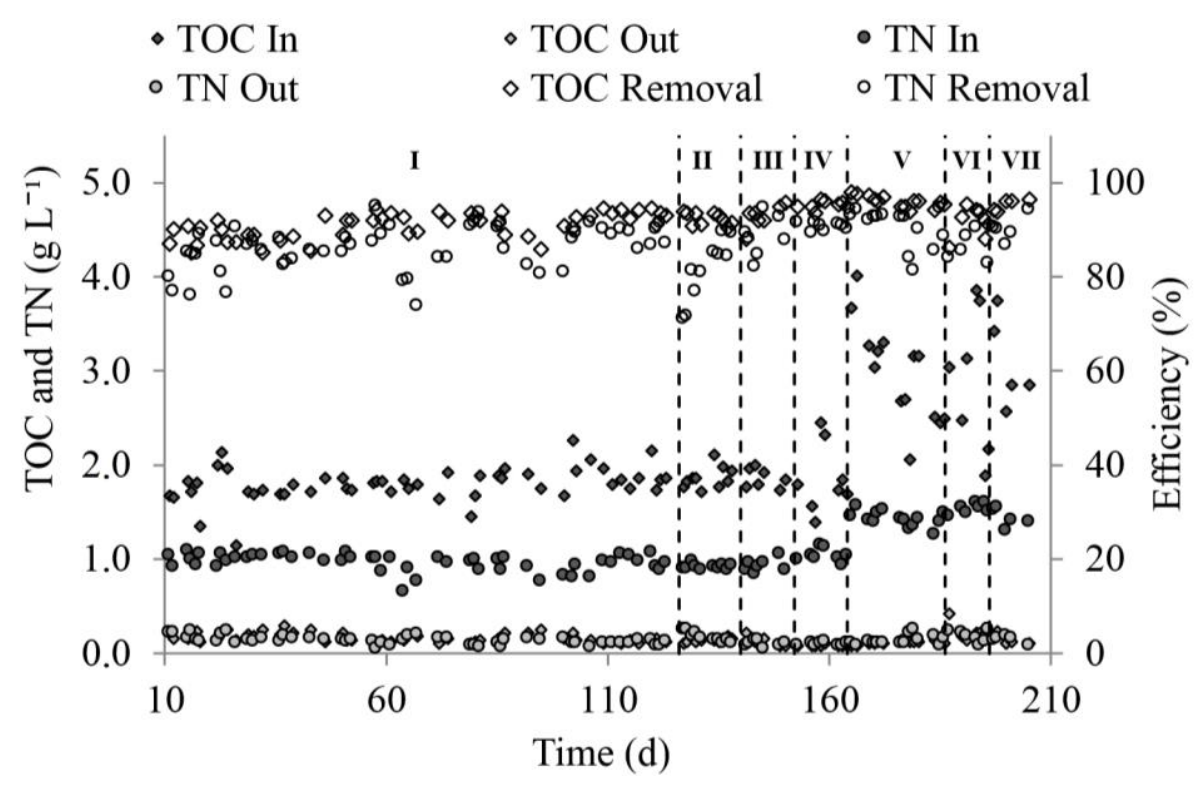

Figure 5. TOC and TN removal efficiencies in a MLE system under different carbon and nitrogen influent concentrations.

The final effluent obtained at the exit of the MLE system was relatively transparent, oxidized, and odorless, with $1.9 \mathrm{mg} \mathrm{L}^{-1}$ of $\mathrm{NH}_{3}-\mathrm{N}, 161.2 \mathrm{mg} \mathrm{L}^{-1}$ of $\mathrm{NO}_{3}-\mathrm{N}+\mathrm{NO}_{2}-\mathrm{N}$, and $144.7 \mathrm{mg} \mathrm{L}^{-1}$ of TOC. These are physical-chemical parameters that meet water quality standards that permit the reuse of water to wash swine facilities (Kunz et al., 2012).

\section{CONCLUSIONS}

The lab scale MLE reactor was continuously fed swine wastewater effluent for over 210 days under different $\mathrm{N}$ and TOC loading rates and HRT operational conditions. Dilution of swine wastewater effluent at the reactor's startup minimized acclimation time required to reach steady state conditions. Denitrification and nitrification conditions were established after 12 and 32 days, respectively. $\mathrm{NH}_{3}$ oxidation above $95 \%$ was achieved. Denitrification efficiencies $>90 \%$ were observed under different $\mathrm{N}$ and TOC influent loading rates and HRT. The highest total nitrogen removal of $89 \%$ was accomplished by recycling effluent from the nitrification reactor (4.5:1) together with the effluent from the clarifier (1:1). HRT as low as 3.5 days $\left(\mathrm{L}_{\mathrm{TN}}\right.$ of $0.56 \mathrm{~g} \mathrm{~L}^{-1} \mathrm{~d}^{-1}$ and $\mathrm{L}_{\mathrm{TOC}}$ of $\left.2.15 \mathrm{~g} \mathrm{~L}^{-1} \mathrm{~d}^{-1}\right)$ led to nitrogen and TOC removal efficiencies > $90 \%$.

This study demonstrated that nitrogen-rich swine wastewater effluent can be efficiently treated by the MLE process. Changes in raw wastewater physical-chemical composition and/or operational conditions should not significantly affect $\mathrm{N}$ and TOC removal efficiencies. This denotes the robustness of the approach and its potential application to field-scale operations.

\section{ACKNOWLEDGMENTS}

The authors thank the CNPq for its financial support.

\section{REFERENCES}

ANTHONISEN, A. C.; LOEHR, R. C.; PRAKASAM, T. B. S.; SRINATH, E. G. Inhibition of nitrification by ammonia and nitrous acid. Journal Water Pollution Control Federation, v. 48, p. 835-852, 1976. https://www.jstor.org/stable/25038971 
APHA; AWWA; WEF. Standard methods for the examination of water and wastewater. 21th ed. Washington, DC, 2012.

CASTRILLÓN, L.; FERNÁNDEZ-NAVA, Y.; MARAÑÓN, E.; GARCÍA, L.; BERRUETA, J. Anoxic-aerobic treatment of the liquid fraction of cattle manure. Waste Management, v. 29, p. 761-766, 2009. https://doi.org/10.1016/j.wasman.2008.06.027

DE PRÁ, M. C. et al. Simultaneous removal of TOC and TSS in swine wastewater using the partial nitritation process. Journal of Chemical Technology \& Biotechnology, v. 87, n. 12, p. 1641-1647, 2012. http://dx.doi.org/10.1002/jctb.3803

HAFEZ, H.; ELBESHBISHYA, E.; CHOWDHURYA， N.; NAKHLAA， B.G.; FITZGERALDC, J.; VAN ROSSUMC, A.; GAULDC, G. Pushing the hydraulic retention time envelope in Modified Ludzack Ettinger systems. Chemical Engineering Journal, v. 163, p. 202-211, 2010. https://doi.org/10.1016/j.cej.2010.07.033

JUBANY, I.; CARRERA, J.; LAFUENTE, J.; BAEZA, J. A. Start-up of a nitrification system with automatic control to treat highly concentrated ammonium wastewater: Experimental results and modeling. Chemical Engineering Journal, v. 144, p.407-419, 2008. https://doi.org/10.1016/j.cej.2008.02.010

KUNZ, A.; STEINMETZ, R. L. R.; DAMASCENO, S.; COLDEBELA, A. Nitrogen removal from swine wastewater by combining treated effluent with raw manure. Scientia Agricola, v. 69, p. 352-356, 2012. http://dx.doi.org/10.1590/S0103-90162012000600002

LEE, Y. S.; HAN, G. B. Pig slurry treatment by a hybrid multi-stage unit system consisting of an ATAD and an EGSB followed by a SBR reactor. Biosystems Engineering, v. 111, p. 243-250, 2012. https://doi.org/10.1016/j.biosystemseng.2011.11.014

LOUGHRIN, J. H.; VANOTTI, M. B.; SZOGI, A. A.; LOVANH, N. Evaluation of SecondGeneration Multistage Wastewater Treatment System for the Removal of Malodors from Liquid Swine Waste. Journal of Environmental Quality, v. 4, p. 23-38, 2009. http://dx.doi.org/10.2134/jeq2008.0430

LUDZACK, F. J.; ETTINGER, M. B. Controlling operation to minimize activated sludge effluent nitrogen. Journal (Water Pollution Control Federation), v. 34, p. 920-931, 1962. https://www.jstor.org/stable/25034693

ORDAZ, A.; OLIVEIRA, C. S.; AGUILAR, R.; CARRIÓN, M.; FERREIRA, E. C.; ALVES, M.; THALASSO, F. Kinetic and Stoichiometric Parameters Estimation in a Nitrifying Bubble Column Through "In-Situ', Pulse Respirometry. Biotechnology and Bioengineering, v. 100, p.94-102, 2008. https://doi.org/10.1002/bit.21723

PARK, J. J. et al. Use of spent sulfidic caustic for autotrophic denitrification in the biological nitrogen removal processes: Lab-scale and pilot-scale experiments, Journal of Industrial and Engineering Chemistry, v. 15, p. 316-322, 2009. https://doi.org/10.1016/j.jiec.2008.11.008

RAJAGOPAL, R.; ROUSSEAU, P.; BERNETC, N.; BÉLINE, F. Combined anaerobic and activated sludge anoxic/oxic treatment for piggery wastewater. Bioresource Technology, v. 102, p. 2185-2192, 2011. https://doi.org/10.1016/j.biortech.2010.09.112

RONGSAYAMANONT, C.; LIMPIYAKORN, T.; LAW, B.; KHAN, E. Relationship between respirometric activity and community of entrapped nitrifying bacteria: Implications for partial nitrification. Enzyme and Microbial Technology, v. 46, p. 229-236, 2010. https://doi.org/10.1016/j.enzmictec.2009.10.014 
TECHIO, V. H.; STOLBERG, J.; KUNZ, A.; ZANIN, E.; PERDOMO, C. C. Genotoxicity of swine effluents. Water Science \& Technology, v. 63, p. 970-976, 2011. http://dx.doi.org/10.2166/wst.2011.278

TCHOBANOGLOUS, G.; ABU-ORF, M.; BURTON, F. L. et al. Wastewater Engineering: Treatment and Resource Recovery. Volume 2. New York: McGraw-Hill Education, 2014.

VANOTTI, M. B.; SZOGI, A. A.; MILLNER, P. D.; LOUGHRIN J. H. Development of a second-generation environmentally superior technology for treatment of swine manure in the USA. Bioresource Technology, v. 100, p. 5406-5416, 2009. https://doi.org/10.1016/j.biortech.2009.02.019

VIANCELLI, A.; KUNZ, A.; STEINMETZ, R. L. R.; KICH, J. D.; SOUZA, C. K.; CANAL, C. W.; COLDEBELLA, A.; ESTEVES, P. A.; BARARDI, C. R. M. Performance of two swine manure treatment systems on chemical composition and on the reduction of pathogens. Chemosphere, v. 90, p. 1317-1572, 2013. https://doi.org/10.1016/j.chemosphere.2012.08.055 